\title{
OPTIMASI PROSES KLASTERISASI DI MYSQL DBMS DENGAN MENGINTEGRASIKAN ALGORITME MIC-KMEANS MENGGUNAKAN BAHASA SQL DALAM STORED PROCEDURE
}

\author{
Issa Arwani *1 \\ ${ }^{1}$ Fakultas Ilmu Komputer, Universitas Brawijaya \\ Email: ${ }^{1}$ issa.arwani@ub.ac.id \\ *Penulis Korespondensi
}

(Naskah masuk: 31 Oktober 2019, diterima untuk diterbitkan: 11 Februari 2020)

\begin{abstract}
Abstrak
Proses klasterisasi data di $D B M S$ akan lebih efisien jika dilakukan langsung di dalam $D B M S$ itu sendiri karena $D B M S$ mendukung untuk pengelolaan data yang baik. SQL-Kmeans merupakan salah satu metode yang sebelumnya telah digunakan untuk mengintegrasikan algoritme klasterisasi $K$-means ke dalam $D B M S$ menggunakan $S Q L$. Akan tetapi, metode ini juga membawa kelemahan dari algoritme $K$-means itu sendiri yaitu lamanya iterasi untuk mencapai konvergen dan keakuratan hasil klasterisasi yang belum optimal akibat dari proses inisialisasi centroid awal secara acak. Algoritme Median Initial Centroid (MIC)-Kmeans merupakan pengembangan dari algoritme $K$-means yang bisa memberikan solusi optimal dalam menentukan awal centroid yang berdampak pada keakuratan dan lamanya iterasi. Dengan keunggulan yang dimiliki algoritme $M I C$ Kmeans, maka dalam penelitian ini dipilih sebagai alternatif algoritme yang diintegrasikan dalam proses klasterisasi data secara langsung di $D B M S$ menggunakan $S Q L$. Proses integrasinya meliputi 4 tahap yaitu tahap inisialisasi tabel dataset, tahap pemetaan algoritme MIC-Kmeans pada SQL dan tabel dataset, tahap perancangan $S Q L$ untuk tiap hasil pemetaan dan tahap implementasi rancangan $S Q L$ dalam MySQL stored procedure. Hasil pengujian menunjukkan bahwa metode $S Q L$ MIC-Kmeans bisa mengurangi $43 \%$ jumlah iterasi dan mengurangi $39 \%$ waktu yang dibutuhkan dari metode SQL-Kmeans untuk mencapai konvergen. Selain itu, nilai rata-rata silhouette coefficient metode SQL MIC-Kmeans adalah 0,79 dan masuk dalam kategori strong structure (nilai rentang 0,7 sampai 1). Sedangkan nilai rata-rata silhouette coefficient metode SQL-Kmeans adalah 0,68 dan masuk dalam kategori medium structure (nilai rentang 0,5 sampai 0,7).
\end{abstract}

Kata kunci: clustering, SQL-kmeans, MIC-kmeans, MySQL stored procedure

\section{OPTIMIZATION OF THE CLASTERIZATION PROCESS IN MYSQL DBMS BY INTEGRATING MIC-KMEANS ALGORITHM USING SQL LANGUAGE IN STORED PROCEDURE}

\begin{abstract}
The process of data clustering in the DBMS will be more efficient because the DBMS supports good data management. SQL-Kmeans is a method that has been used to integrate K-means clustering algorithms into DBMS using SQL. However, it carries the weakness of the K-means algorithm itself in the duration of iterations to reach convergence and the accuracy of clustering due to the centroid initialization process randomly. Median Initial Centroid (MIC)-Kmeans algorithm is a development of the K-means algorithm that can provide the optimal solution in determining the initial centroid which has an impact on the accuracy and duration of iterations. With the advantages of the MIC-Kmeans algorithm, the method was chosen as an alternative algorithm to be integrated in the DBMS using SQL for a clustering. The integration process includes 4 stages, there are dataset initialization, SQL algorithm mapping and dataset table, SQL design for each mapping result, and implementation SQL in the MySQL stored procedure. The test results show that the SQL MIC-Kmeans method can reduce $43 \%$ the number of iterations and reduce $39 \%$ of the time required from the SQL-Kmeans method to reach convergence. In addition, the average value of the coefficient SQL MIC-Kmeans method is 0.79 and categorized as strong structure (value ranges from 0.7 to 1). While, the average value of the coefficient SQL-Kmeans method is 0.68 and categorized as medium structure (value ranges from 0.5 to 0.7 ).
\end{abstract}

Keywords: clustering, SQL-kmeans, MIC-kmeans, MySQL stored procedure 


\section{PENDAHULUAN}

Secara umum, proses klasterisasi data yang tersimpan di dalam Database Management System (DBMS) dilakukan oleh aplikasi di luar $D B M S$ dengan cara mengambil data dari $D B M S$ terlebih dahulu, kemudian disimpan sementara dalam struktur data program (misal dalam sebuah array atau list) untuk diproses lebih lanjut dengan menggunakan algoritme klasterisasi. Proses klasterisasi yang dilakukan di luar $D B M S$ perlu mempertimbangkan beberapa aspek, diantaranya waktu yang dibutuhkan dalam proses pengambilan data, kualitas data, keamanan data, fleksibilitas dimensi data dan kemampuan aplikasi mengolah data dalam jumlah yang besar. Sehingga, proses klasterisasi data akan lebih efisien jika dilakukan langsung di dalam $D B M S$ itu sendiri karena $D B M S$ mendukung untuk pengelolaan data yang baik (Ordonez, García 2016).

Standard Query Language (SQL) adalah bahasa standar yang digunakan untuk mengakses dan mengelola data serta tersedia pada semua $D B M S$. Proses klasterisasi data dalam $D B M S$ bisa diimplementasikan dengan menggunakan $S Q L$ meskipun $S Q L$ sendiri memiliki kelemahan dalam mengoperasikan proses matematika yang komplek terutama dalam pengolahan data matrik. $S Q L$ Kmeans merupakan salah satu metode yang sebelumnya telah diimplementasikan dengan mengintegrasikan algoritme klasterisasi $K$-means ke dalam DBMS menggunakan SQL (Arwani, 2015). Akan tetapi, algoritme K-means yang diimplementasikan menggunakan $S Q L$ akan membawa kelemahan dari algoritme K-means itu sendiri yaitu keakuratan dan lamanya iterasi untuk mencapai konvergen (Katara, Juhi, \& Naveen, 2015). Sehingga, diperlukan pemilihan algoritme alternatif dari pengembangan algoritme K-means yang bisa diimplementasikan menggunakan $S Q L$ dengan mempertimbangkan kelemahan dari $S Q L$ itu sendiri.

Pengembangan algoritme K-means dalam penentuan awal centroid yang berdampak pada keakuratan dan lamanya iterasi untuk mencapai konvergen sudah banyak dilakukan. Algoritme Median Initial Centroid (MIC)-Kmeans menggunakan perhitungan median interkuartil dari masing-masing atribut untuk menentukan initial centroid tiap klasternya (Premkumar, Ganesh, 2017). Algoritme Radial and Angular Coordinates (RAC)-Kmeans menggunakan perhitungan $n$ spherical coordinate system dan Cartesian coordinate system untuk menentukan awal centroid (Rahim, Ahmed, 2017). Algoritme Distance Part (DP-KMeans) menggunakan metode nilai tengah dari dataset yang sudah dinormalisasi dan diurutkan untuk menentukan awal centroid (Ilham, Ibrahim, 2018).

Dari ketiga referensi pengembangan algoritme K-means diatas, algoritme MIC-Kmeans memiliki proses matematika yang paling sederhana dan kompleksitas waktu asimptotik yang paling rendah dalam menentukan nilai awal centroid. Sehingga, algoritme MIC-Kmeans dalam penelitian ini dipilih sebagai alternatif algoritme yang diintegrasikan dalam proses klasterisasi data secara langsung di $D B M S$ menggunakan SQL. Selanjutnya, permasalahan yang diangkat dalam penelitian ini adalah bagaimana inisialisasi tabel dataset dan perancangan $S Q L$ untuk memetakan setiap tahap algoritme klasterisasi MIC-Kmeans. Hasil dari setiap tahap rancangan $S Q L$ kemudian diintegrasikan dalam MySQL stored procedure untuk bisa diimplementasikan di DBMS. Terakhir, pengujian dan evaluasi dilakukan pada data uji coba dengan berbagai varian jumlah dataset dan klaster.

\section{METODE PENELITIAN}

Metode yang digunakan dalam penelitian ini ditunjukkan pada Gambar 1 yang meliputi 5 tahap yaitu tahap inisialisasi tabel dataset, tahap pemetaan algoritme pada $S Q L$ dan tabel dataset, tahap perancangan $S Q L$ untuk tiap hasil pemetaan, tahap implementasi rancangan $S Q L$ dalam MySQL stored procedure dan tahap pengujian beserta analisis hasilnya. Berikut penjelasan detail tentang tiap tahap dari metode penelitian yang digunakan:

\section{a. Inisialisasi tabel dataset}

Pada tahap ini, didefinisikan tabel-tabel yang merupakan representasi dari dataset yang dibutuhkan dalam setiap tahap algoritme klasterisasi MIC-Kmeans.

b. Pemetaan algoritme $M I C-K m e a n s$ pada $S Q L$ dan tabel dataset

Pada tahap ini, dilakukan pemetaan $S Q L$ yang dibutuhkan dalam pengoperasian setiap tahap algoritme klasterisasi MIC-Kmeans terhadap tiap tabel dataset yang bersesuaian sebagai tempat penyimpanan hasil pengolahan data.

c. Perancangan $S Q L$ untuk tiap tahap hasil pemetaan

Pada tahap ini, dilakukan perancangan $S Q L$ berdasarkan hasil pemetaan setiap tahap proses operasi algoritme klasterisasi MIC-Kmeans.

\section{d. Implementasi rancangan $S Q L$ dalam $M y S Q L$} stored procedure

Pada tahap ini, dilakukan implementasi rancangan $S Q L$ pada tahap sebelumnya ke dalam stored procedure supaya bisa dioperasikan dalam DBMS $M Y S Q L$ melalui pemanggilan stored procedure utama.

\section{e. Pengujian dan analisis hasil pengujian}

Pada tahap ini, dilakukan pengujian dan analisis hasil dari berbagai varian jumlah dataset. Pengujian dilakukan dengan membandingkan hasil kinerja klasterisasi dataset antara metode $S Q L$ Kmeans dengan SQL MIC-Kmeans di DBMS $M y S Q L$ dari sisi banyaknya iterasi dan waktu yang diperlukan untuk mencapai konvergen serta kualitas 
hasil klasterisasi yang ditunjukkan dengan nilai ratarata silhouette coefficient (Govinda, Varaprasada, \& Rambabu, 2018).

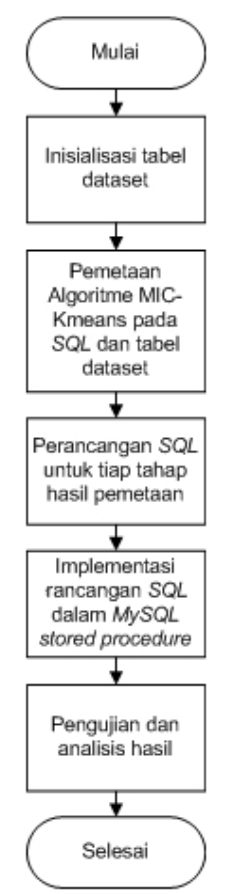

Gambar 1 Metode Penelitian

\section{PROSES INTEGRASI ALGORITME $M I C$ - KMEANS KE DALAM DBMS MYSQL}

\subsection{Inisialisasi tabel dataset}

Ada beberapa istilah tabel yang digunakan dalam penyimpanan hasil pemrosesan setiap tahap algoritme MIC-Kmeans yang direpresentasikan dalam tabel dataset. Pada tahap ini dilakukan inisialisasi tabel menggunakan pernyataan Data Definition Language (DDL). Ada sepuluh tabel dataset yang didefinisikan diawal seperti ditunjukkan pada Tabel 1. Kolom yang diberi tanda garis bawah dari masing - masing tabel merupakan primary key dari tabel tersebut. Sedangkan subscript $i, j, l$ secara berturut-turut adalah jumlah dataset, jumlah klaster dan jumlah dimensi dari dataset.

\subsection{Pemetaan algoritme $M I C-K m e a n s$ terhadap SQL dan tabel dataset}

Komponen utama dalam memetakan algoritme MIC-Kmeans ke dalam bahasa $S Q L$ yaitu bagaimana mengekspresikan perhitungan matrik dari algoritme MIC-Kmeans ke dalam tabel dataset dengan mendesain $S Q L$ untuk setiap tahapnya. Tabel 2 menggambarkan $S Q L$ yang dibutuhkan berdasarkan pemetaan setiap tahap algoritme MIC-Kmeans yang mana hasilnya akan disimpan dalam tabel-tabel dataset yang bersesuaian.
Tabel 1. Dataset

\begin{tabular}{|c|c|c|}
\hline $\begin{array}{c}\text { Tabel } \\
\text { Dataset }\end{array}$ & Kolom & Keterangan \\
\hline YH & $\begin{array}{l}\underline{\mathrm{i}}, \mathrm{Y} 1, \mathrm{Y} 2, \ldots, \\
\mathrm{Y} l\end{array}$ & $\begin{array}{l}\text { Tabel yang berisi dataset sebanyak } i \\
\text { baris data dan } l \text { kolom (dimensi). }\end{array}$ \\
\hline YV & $\underline{\mathrm{i}}, \underline{l}$, val & $\begin{array}{l}\text { Tabel yang berisi nilai val untuk } \\
\text { masing-masing baris ke } i \text { dan } \\
\text { dimensi } l \text { dari tabel } Y H \text {. }\end{array}$ \\
\hline YVsort & $\underline{\mathrm{i}}, \underline{l}$, val & $\begin{array}{l}\text { Tabel yang berisi data val yang } \\
\text { sudah diurutkan nilainya dari tabel } \\
Y V \text { untuk masing-masing dimensi } l \text {. }\end{array}$ \\
\hline Cmed & $\mathrm{i}, \underline{\mathrm{m}}$, val & $\begin{array}{l}\text { Tabel yang berisi baris ke } i \text { dari } \\
\text { tabel YVsort untuk menentukan nilai } \\
\text { val berdasarkan nilai median } \\
\text { interkuartil } m \text { tiap klaster } j \text {. }\end{array}$ \\
\hline $\mathrm{CV}$ & $\mathrm{j}, \underline{l}$, val & $\begin{array}{l}\text { Tabel yang berisi val dari nilai } \\
\text { median interkuartil tiap klaster } j \\
\text { untuk masing-masing dimensi } l \text {. }\end{array}$ \\
\hline YD & $\underline{\mathrm{i}}, \mathrm{j}$, dist & $\begin{array}{l}\text { Tabel yang berisi nilai jarak dist } \\
\text { untuk masing-masing data ke } i \\
\text { dengan klaster } j\end{array}$ \\
\hline YNN & $\underline{\mathrm{i}}, \mathrm{j}$ & $\begin{array}{l}\text { Tabel yang berisi hasil klaster } j \\
\text { untuk masing-masing data baris ke } i\end{array}$ \\
\hline $\mathrm{R}$ & $\mathrm{j}, \underline{l}$, val & $\begin{array}{l}\text { Tabel yang berisi nilai varian val } \\
\text { berdasarkan nilai centroid yang baru } \\
\text { pada tabel } C V\end{array}$ \\
\hline W & $\mathrm{j}, \mathrm{w}$ & $\begin{array}{l}\text { Tabel yang berisi jumlah/bobot } w \\
\text { dari data untuk setiap klaster } j\end{array}$ \\
\hline model & $\begin{array}{l}\text { Avg_q, } \\
\text { iteration }\end{array}$ & $\begin{array}{l}\text { Tabel yang berisi nilai error } A v g \_q \\
\text { untuk menentukan konvergen dan } \\
\text { nilai iteration untuk menyimpan } \\
\text { banyaknya iterasi }\end{array}$ \\
\hline
\end{tabular}

Tabel 2. Pemetaan tiap tahap algoritme $M I C$-Kmeans terhadap $S Q L$ dan tabel dataset

\begin{tabular}{|c|c|c|}
\hline Tahap & MIC-Kmeans & SQL MIC-Kmeans \\
\hline 1 & Inisialisasi dataset & $\begin{array}{l}S Q L \text { untuk inisialisasi data dari } \\
\text { dataset yang diisikan pada tabel } Y H \\
\text { dan } Y V\end{array}$ \\
\hline 2 & $\begin{array}{l}\text { Sorting dataset } \\
\text { untuk masing- } \\
\text { masing atribut }\end{array}$ & $\begin{array}{l}S Q L \text { untuk sorting tiap atribut data } \\
\text { dari tabel } Y V \text { yang kemudian diisikan } \\
\text { pada tabel } Y v \text { sort. }\end{array}$ \\
\hline 3 & $\begin{array}{l}\text { Menentukan nilai } \\
\text { median } \\
\text { interkuartil klaster } \\
\text { untuk masing- } \\
\text { masing atribut } \\
\text { sebagai initial } \\
\text { centroid }\end{array}$ & $\begin{array}{l}S Q L \text { untuk menghitung nilai median } \\
\text { dari tabel Yvsort tiap klaster sebagai } \\
\text { initial centroid dan diisikan pada } \\
\text { tabel Cmed dan } C V\end{array}$ \\
\hline 4 & $\begin{array}{l}\text { Menghitung jarak } \\
\text { setiap data pada } \\
\text { centroid }\end{array}$ & $\begin{array}{l}S Q L \text { untuk menghitung jarak antara } \\
\text { data tabel } Y V \text { dengan tabel } C V \text { dan } \\
\text { diisikan pada tabel } Y D\end{array}$ \\
\hline 5 & $\begin{array}{lr}\text { Mengelompokkan } \\
\text { data } & \text { berdasarkan } \\
\text { jarak } & \text { terdekat } \\
\text { dengan } & \text { centroid }\end{array}$ & $\begin{array}{l}S Q L \text { untuk memilih jarak terdekat } \\
\text { dari tabel } Y D \text { untuk masing-masing } \\
\text { data terhadap centroid dan diisikan } \\
\text { pada tabel } Y N N\end{array}$ \\
\hline 6 & $\begin{array}{l}\text { Memutakhirkan } \\
\text { centroid baru }\end{array}$ & $\begin{array}{l}S Q L \text { untuk memperbarui data pada } \\
\text { tabel } C V\end{array}$ \\
\hline 7 & $\begin{array}{l}\text { Cek nilai } \\
\text { konvergen }\end{array}$ & $\begin{array}{l}S Q L \text { untuk memperbarui data pada } \\
\text { tabel } W, R \text { dan model }\end{array}$ \\
\hline 8 & $\begin{array}{l}\text { Tahap 4-7 diulang } \\
\text { hingga konvergen } \\
\text { bernilai true }\end{array}$ & $\begin{array}{l}\text { Tahap 4-7 diulang hingga nilai } A v g \_q \\
\text { pada tabel model konvergen }\end{array}$ \\
\hline
\end{tabular}

\subsection{Perancangan $S Q L$ tiap tahap hasil pemetaan}

Perancangan $S Q L$ dilakukan berdasarkan hasil pemetaan setiap tahap proses operasi algoritme klasterisasi MIC-Kmeans. Berikut detail perancangan $S Q L$ untuk setiap tahapnya:

Tahap 1: Perancangan $S Q L$ untuk inisialisasi dataset yang diisikan pada tabel $Y H$ dan $Y V$. Tabel $Y H$ diisi dengan pernyataan $S Q L$ sebagai berikut: 
INSERT INTO YH

SELECT @n: $=@ n+1 i, \mathrm{Y} 1, \mathrm{Y} 2, \ldots, \mathrm{Y} l$

FROM <dataset_table>, (SELECT @ $n:=0) \mathrm{m}$;

Pernyataan $@ n:=@ n+1$ i dan $($ SELECT $@ n:=0) m$ digunakan untuk fungsi incremental yang memberikan nilai unik dari kolom primary key $i$ pada tabel $Y H$. Sedangkan Tabel $Y V$ diisi dengan pernyataan $S Q L$ sebagai berikut:

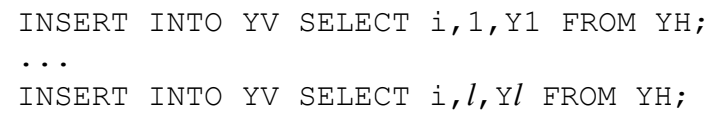

Tahap 2: Perancangan $S Q L$ untuk sorting tiap atribut data dari tabel $Y V$ yang kemudian diisikan pada tabel Yvsort. Tabel Yvsort diisi dengan pernyataan $S Q L$ sebagai berikut:

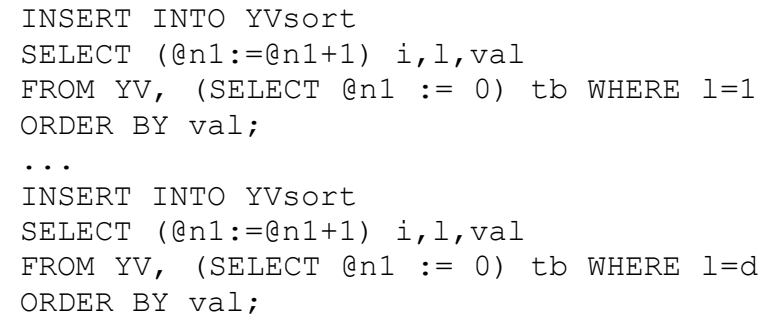

Tahap 3: Perancangan $S Q L$ untuk menghitung nilai median dari tabel Yvsort tiap klaster $k$ sebagai initial centroid dan diisikan pada tabel Cmed dan $C V$. Tabel Cmed diisi dengan pernyataan $S Q L$ sebagai berikut:

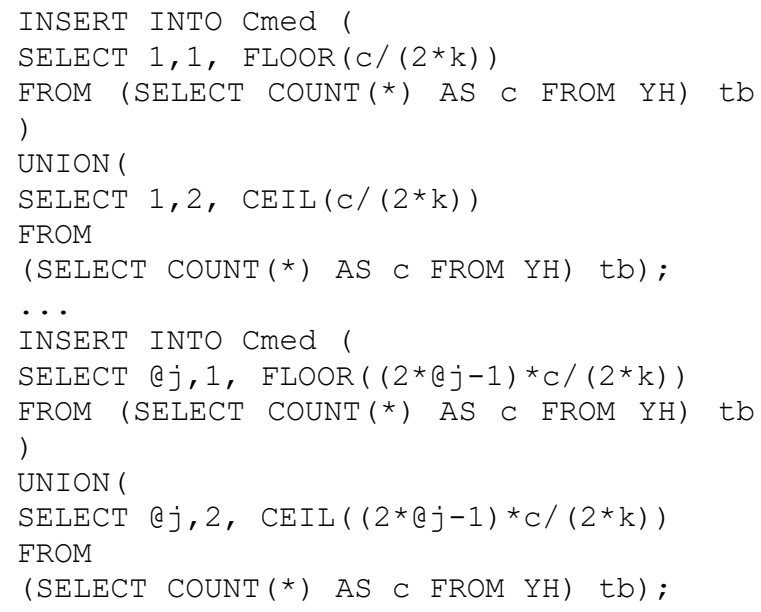

Sedangkan Tabel $C V$ diisi dengan pernyataan $S Q L$ sebagai berikut:

INSERT INTO CV

SELECT j, l, AVG (yvsort.val)

FROM yvsort, ch WHERE yvsort.i=ch.val GROUP BY j, l;

Tahap 4: Perancangan $S Q L$ untuk menghitung jarak antara data tabel $Y V$ dengan tabel $C V$ dan diisikan pada tabel $Y D$. Tabel $Y D$ diisi dengan pernyataan $S Q L$ sebagai berikut:

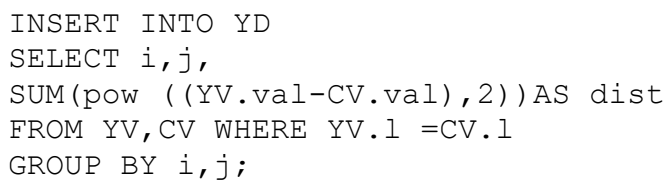

Tahap 5: Perancangan $S Q L$ untuk memilih jarak terdekat dari tabel $Y D$ untuk masing-masing data terhadap centroid dan diisikan pada tabel $Y N N$. Tabel $Y N N$ diisi dengan pernyataan $S Q L$ sebagai berikut:

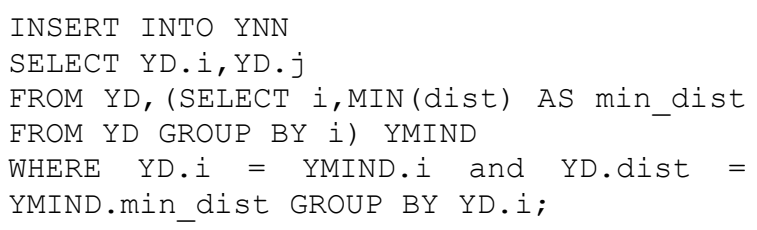

Tahap 6: Perancangan $S Q L$ untuk memperbarui data tabel $C V$. Tabel $C V$ diisi dengan pernyataan $S Q L$ sebagai berikut:

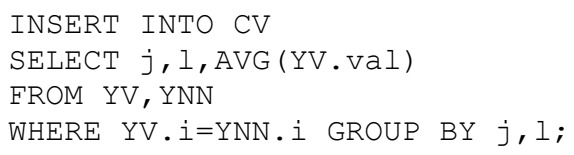

Tahap 7: Perancangan $S Q L$ untuk memperbarui data tabel $W, R$ dan model. Tabel $W, R$ dan model diisi dengan pernyataan $S Q L$ sebagai berikut:

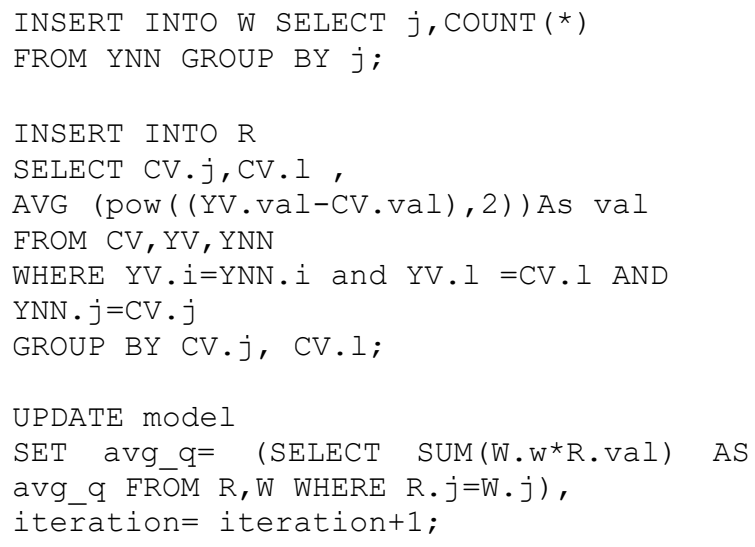

\subsection{Implementasi rancangan $S Q L$ dalam $M y S Q L$ Stored Procedure}

Setiap perancangan $S Q L$ yang telah didefinikan pada tahap 1 sampai dengan tahap 7 kemudian diimplementasikan dalam MySQL stored procedure. Tabel 3 menggambarkan detail lengkap untuk masing-masing isi dari stored procedure. Nama stored procedure diambilkan dari setiap tahap pemetaan algoritme terhadap tabel dataset yang berkolerasi. Di akhir tabel, ditambahkan sebuah stored procedure utama untuk memanggil setiap tahap stored procedure hingga proses klasterisasi konvergen. 
Tabel 3. Implementasi rancangan $S Q L$ dalam MySQL Stored Procedure

\begin{tabular}{|c|c|}
\hline No & Implementasi Stored Procedure \\
\hline 1 & 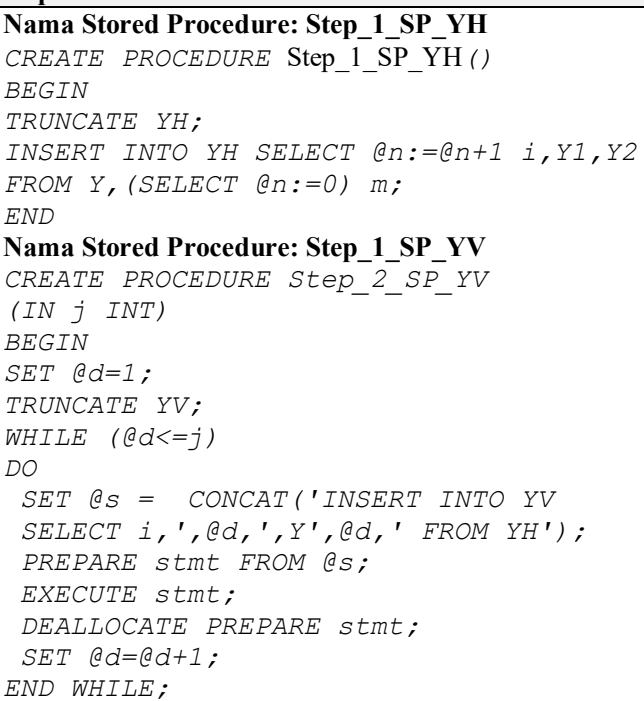 \\
\hline
\end{tabular}

2 Nama Stored Procedure: Step_2_SP_YVsort

CREATE PROCEDURE Step_2_SP YVsort(IN j INT)

$B E G I N$

SET $\mathrm{dd}=1$

TRUNCATE YVSOrt

WHILE $\quad(@ d<=j)$

DO

INSERT INTO YVSOrt

SELECT (anl := anl + 1) i, l, val

FROM YV, (SELECT anI $:=0)$ tb

WHERE I=@d ORDER BY Val;

SET $Q d=@ d+1$;

END WHILE;

END

3 Nama Stored Procedure: Step 3 SP Cmed

CREATE Step_3_SP_Cmed ( $(\overline{I N} \bar{k}$ INT) $B E G I N$

SET $\quad 0 j=1$;

TRUNCATE CMEd;

WHILE $\quad(\Theta j<=k)$

DO

insert into Cmed (

select $\theta j, 1, F L O O R\left(\left(2 *(a j-1) *_{C} /(2 * k)\right)\right.$

from(select count(*) as $C$ from $Y H$ ) tb)

UNION (

select $0 j, 2, \operatorname{CEIL}\left(\left(2 \star^{*}(j-1) \star_{C} /\left(2 \star^{*}\right)\right)\right.$

from (select count(*) as C from $Y H$ ) tb);

SET $@ j=0 j+1$;

END WHILE;

END

Nama Stored Procedure: Step 3 SP CV

CREATE Step_3_SP_CV()

$B E G I N$

TRUNCATE CV;

INSERT INTO CV SELECT j,l, AVG (yvSort.val)

FROM yvsort, ch WHERE yvsort. $i=c h$. val

GROUP BY j, l;

END

4 Nama Stored Procedure: Step_4_SP_YD

CREATE PROCEDURE SteP_4_SP- YD()

$B E G I N$

TRUNCATE YD;

INSERT INTO YD

SELECT i,j,SUM(pow ((YV.Val-CV.Val), 2)) AS dist $F R O M Y V, C V$ WHERE YV.I =CV.I GROUP BY $i, j$; END

5 Nama Stored Procedure: Step_5_SP_YNN CREATE Step 5 SP YNN()
BEGIN

TRUNCATE YNN;

INSERT INTO YNN

SELECT YD.i,YD.j

FROM YD, (SELECT i,MIN(dist) AS min_dist

FROM YD GROUP BY i) YMIND

WHERE YD.i = YMIND. $i$ AND YD.dist = YMIND.min_dist GROUP BY YD.i;

END

6 Nama Stored Procedure: Step_6_SP_CV

CREATE PROCEDURE Step 6 SP $C V()$

$B E G I N$

TRUNCATE CV;

INSERT INTO CV

SELECT j, l, AVG (YV.Val)

FROM YV, YNN

WHERE YV.i=YNN.i GROUP BY j,l;

END

7 Nama Stored Procedure: Step 7 SP W R MODEL

CREATE PROCEDURE Step $\overline{7} \overline{S P}_{\bar{W}} \overline{\mathrm{W}}-\mathrm{MODEL}($

$B E G I N$

TRUNCATE $W$; TRUNCATE R;

INSERT INTO W SELECT j,COUNT (*)

FROM YNN GROUP BY $j$;

INSERT INTO $R$

SELECT CV.j,CV. I , AVG (pow ((YV.VaI-

(V.Val), 2)) As Val

FROM CV, YV, YNN

WHERE YV.i=YNN.I AND YV.I =CV.I AND

$Y N N \cdot j=C V \cdot j$ GROUP BY CV.j, CV. I;

UPDATE model

SET avg_q= (SELECT SUM $\left(W \cdot W^{\star} R\right.$. Val) AS avg q FROM R,W WHERE R.j=W.j),

iteration= iteration +1 ;

END

8 Nama Stored Procedure: Step 8 SP SQL MIC Kmeans CREATE PROCEDURE Step_8_SP_SQL_MIC_Kmeans( IN iterasi INT(11),

IN klaster INT(11),

IN dimensi INT(11))

BEGIN

SET eit $=0$;

SET QX $\mathrm{C}=-1$;

CALL Step_1_SP_YH();

CALL Step 1 SP YV(dimensi);

CALL Step 2 SP YVSort(dimensi);

CALL Step_3_SP_Cmed(klaster);

CALL Step 3 SP CV();

UPDATE mode $\bar{l}$ SET avg_q=0, iteration=0;

WHILE (@x!=(SELECT avg 9 FROM model) AND

(at $<=$ iterasi)

DO

CALL SteP_4_SP_YD();

CALL SteP 5 SP YNN();

SET $A_{X}=(S E L E C T$ avg q FROM model):

CALL SteP_6_SP_CV();

CALL Step 7 SP W R MODEL ();

SET Qit $=0 \bar{i} t+1$;

END WHILE;

END

\section{HASIL DAN PEMBAHASAN}

Pengujian dan evaluasi dilakukan dengan membandingkan kinerja klasterisasi dataset antara metode SQL-Kmeans dengan SQL MIC-Kmeans di $D B M S M y S Q L$ dengan 3 skenario uji coba. Uji coba yang pertama adalah uji coba jumlah iterasi dan waktu yang dibutuhkan untuk mencapai konvergen dengan varian jumlah dataset. Ujicoba yang kedua 
adalah uji coba kualitas klaster dengan metode silhouette coefficient dengan varian jumlah dataset. Sedangkan uji coba yang ketiga adalah ujicoba waktu yang dibutuhkan untuk satu kali iterasi yang kemudian dianalisis dengan perhitungan kompleksitas waktu asimptotik. Pengujian skenario pertama dan kedua dilakukan 5 kali percobaan untuk setiap varian jumlah dan klaster dataset-nya kemudian diambil nilai rata-ratanya. Pengujian dilakukan pada komputer personal (bukan komputer server) dengan spesifikasi memori $4 \mathrm{~GB}$, dan processor intel core i5 cpu 3 Ghz. Dataset yang digunakan adalah data perkembangan Indeks Prestasi Kumulatif (IPK) dan jumlah sks lulus mahasiswa untuk setiap semesternya dengan variasi jumlah dataset 100, 300, 500, 700, dan 900 data.

Dari grafik pada Gambar 2 dan Gambar 3, hasil penelitian menunjukkan bahwa dengan berbagai jumlah varian dataset, maka jumlah rata-rata iterasi dan rata-rata waktu proses klasterisasi untuk mencapai konvergen metode SQL MIC-Kmeans lebih kecil jika dibandingkan dengan metode $S Q L$ Kmeans. Dalam perhitungan persentase, metode SQL MIC-Kmeans bisa mengurangi $43 \%$ jumlah iterasi dan mengurangi 39\% waktu yang dibutuhkan dari metode $S Q L$ MIC-Kmeans untuk mencapai konvergen. Hal tersebut dikarenakan metode $S Q L$ Kmeans pada proses inisialisasi centroid awal dilakukan secara acak yang menyebabkan algoritmenya tidak stabil. Sedangkan metode $S Q L$ $M I C$-Kmeans menggunakan perhitungan median tiap atribut (dimensi) untuk menentukan inisialisasi centroid awal masing-masing klaster sehingga hasilnya lebih optimal.
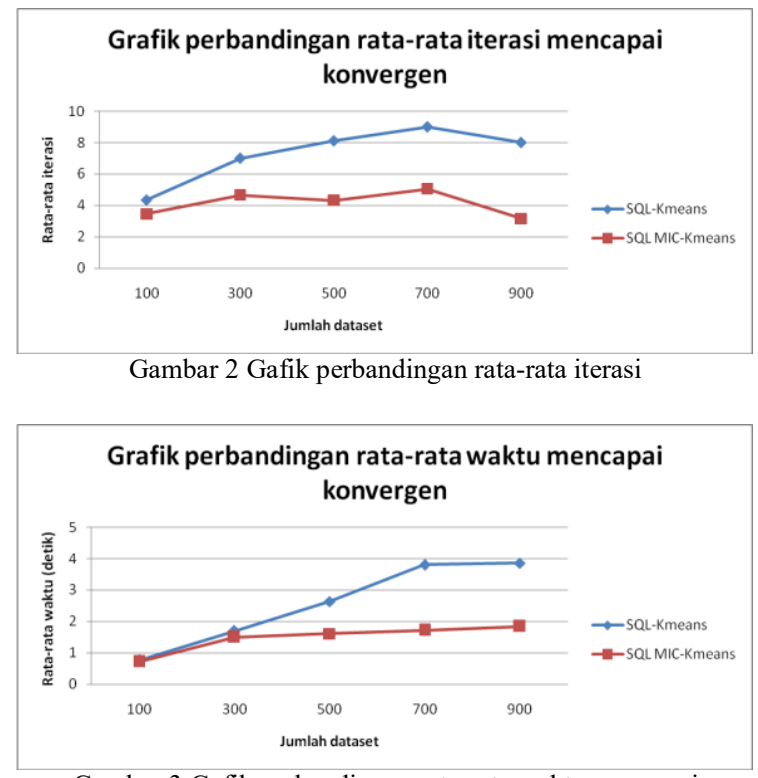

Gambar 3 Gafik perbandingan rata-rata waktu mencapai konvergen

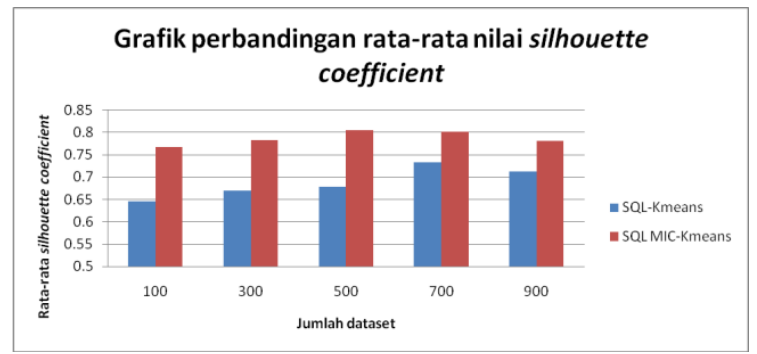

Gambar 4 Gafik perbandingan rata-rata nilai silhouette coefficient

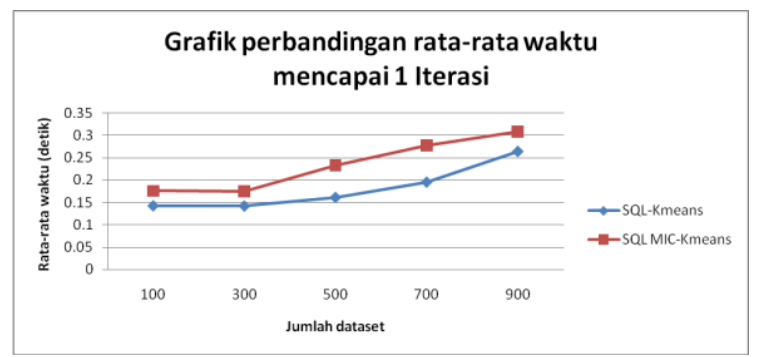

Gambar 5 Gafik perbandingan rata-rata waktu 1 iterasi

Dari grafik pada Gambar 4, hasil penelitian menunjukkan bahwa dengan berbagai jumlah varian dataset, maka nilai rata-rata silhouette coefficient metode SQL MIC-Kmeans lebih tinggi jika dibandingkan dengan metode SQL-Kmeans. Nilai rata-rata silhouette coefficient metode $S Q L$-Kmeans dan SQL MIC-Kmeans masing-masing adalah 0,68 dan 0,79. Berdasarkan nilai rata-rata silhouette coefficient maka metode SQL-Kmeans masuk dalam kategori medium structure (nilai rentang 0,5 sampai 0,7) sedangkan metode $S Q L$ MIC-Kmeans masuk dalam kategori strong structure (nilai rentang 0,7 sampai 1). Hal tersebut juga dikarenakan metode SQL MIC-Kmeans sejak awal telah melakukan optimasi dalam inisialisasi nilai centroid awal sehingga hasil dari klasterisasi juga bisa optimal.

Dari grafik pada Gambar 5, hasil penelitian menunjukkan bahwa dengan berbagai jumlah varian dataset, ternyata waktu yang dibutuhkan untuk 1 iterasi proses klasterisasi dengan metode $S Q L$ Kmeans lebih cepat dari pada metode SQL MICKmeans. Hal tersebut disebabkan karena adanya tambahan proses dalam menentukan inisialisasi nilai centroid awal pada metode SQL MIC-Kmean. Sedangkan dalam metode $S Q L-K m e a n s$, penentuan inisialisasi nilai centroid awal dilakukan secara acak dan hanya membutuhkan satu proses. Hal ini juga bisa dijelaskan dalam perbandingan perhitungan kompleksitas waktu asimptotik untuk masingmasing tahap algoritme dari SQL-Kmeans maupun $S Q L$ MIC-Kmean pada Tabel 4. Pada metode $S Q L$ MIC-Kmean, proses dalam menentukan inisialisasi nilai centroid awal memiliki kompleksitas waktu asimptotik yang lebih tinggi yaitu $O(n d k)$, sedangkan kompleksitas waktu asimptotik pada metode $S Q L$ Kmeans adalah $O(k d)$. 
Tabel 4. Perbandingan kompleksitas waktu asimptotik tiap tahap algoritme SQL-Kmeans dan SQL MIC-Kmeans

\begin{tabular}{lcc}
\hline $\begin{array}{l}\text { LangkahUmum } \\
\text { Algoritme }\end{array}$ & $\begin{array}{c}\text { SQL - } \\
\text { Kmeans }\end{array}$ & $\begin{array}{c}\text { SQL } \boldsymbol{M I C} \text { - } \\
\text { Kmeans }\end{array}$ \\
\hline $\begin{array}{l}\text { 1. Inisialisasi dataset } \\
\begin{array}{l}\text { 2. Inisialisasi centroid } \\
\text { 3. Menghitung jarak }\end{array}\end{array}$ & $\mathrm{O}(\mathrm{nd})$ & $\mathrm{O}(\mathrm{nd})$ \\
$\begin{array}{l}\text { setiap data pada centroid } \\
\text { 4. Mengelompokkan }\end{array}$ & $\mathrm{O}(\mathrm{nkd})$ & $\mathrm{O}(\mathrm{ndk})$ \\
$\begin{array}{l}\text { data berdasarkan jarak } \\
\text { terdekat dengan centroid }\end{array}$ & $\mathrm{O}(\mathrm{nk})$ & $\mathrm{O}(\mathrm{nkd})$ \\
$\begin{array}{l}\text { 5. Memutakhirkan } \\
\text { centroid baru }\end{array}$ & & $\mathrm{O}(\mathrm{nk})$ \\
6. Cek nilai konvergen & $\mathrm{O}(\mathrm{nd})$ & $\mathrm{O}(\mathrm{nd})$ \\
\hline
\end{tabular}

\section{KESIMPULAN}

Proses klasterisasi secara langsung dalam $D B M S$ MYSQL berhasil dilakukan dengan mengintegrasikan algoritme klasterisasi MICKmeans menggunakan SQL. Proses integrasi dilakukan dengan beberapa tahap yang diawali dengan tahap inisialisasi tabel-tabel dataset dalam $D B M S$ menggunakan $D D L$. Kemudian dilanjutkan dengan pemetaan tahap-tahap algoritme $M I C$ Kmeans terhadap pendefinisian $S Q L$ yang dibutuhkan untuk setiap proses operasinya. Perancangan $S Q L$ kemudian dilakukan berdasarkan proses dari setiap tahap algoritme MIC-Kmeans dengan melakukan join tabel-tabel dataset yang bersesuaian. Proses implementasi dilakukan dengan membuat stored procedure untuk masing-masing rancangan $S Q L$ dan dipanggil dalam sebuah stored procedure utama. Hasil pengujian menunjukkan bahwa metode SQL MIC-Kmeans bisa mengurangi $43 \%$ jumlah iterasi dan mengurangi 39\% waktu yang dibutuhkan dari metode SQL-Kmeans untuk mencapai konvergen. Selain itu, nilai rata-rata silhouette coefficient-nya masuk dalam kategori strong structure. Akan tetapi waktu yang dibutuhkan untuk 1 kali iterasi, metode $S Q L-K m e a n s$ lebih cepat dari pada metode SQL MIC-Kmeans. Sehingga, untuk penelitian selanjutnya disarankan untuk bisa dilakukan optimasi $S Q L$-nya.

\section{DAFTAR PUSTAKA}

ARWANI, I., 2015. Integrasi Algoritme K-Means Dengan Bahasa Sql Untuk Klasterisasi Ipk Mahasiswa (Studi Kasus: Fakultas Ilmu Komputer Universitas Brawijaya), 2(2), p. 143-151, Jurnal Teknologi Informasi dan Ilmu Komputer (JTIIK).

GOVINDA, R., VARAPRASADA, R.,RAMBABU, R., 2018. A Novel Approach in Clustering Algorithm to Evaluate the Performance of Regression Analysis, 42(6), p.143-146, IEEE 8th International Advance Computing Conference (IACC).

ILHAM, A., IBRAHIM, D., 2018. Tackling Initial Centroid of K-Means with Distance Part (DP-KMeans), 42(6), p.185-189,
International Symposium on Advanced Intelligent Informatics (SAIN).

KATARA, JUHI, dan NAVEEN C.A., 2015. Modified Version of the K-means Clustering Algorithm, vol. 15, no. 7, Global Journal of Computer Science and Technology.

ORDONEZ, C., GARCÍA, J., 2016. Managing Big Data Analytics Workflows with a Database System, 18(2), p. 649-655, 16th IEEE/ ACM International Symposium on Cluster, Cloud and Grid Computing (CCGrid).

PREMKUMAR, M.S., GANESH, S.H, 2017. A Median Based External Initial Centroid Selection Method for K-Means Clustering, 42(6), p.143-146, Computing and Communication Technologies (WCCCT).

RAHIM, S.M.D., AHMED, T, 2017. An Initial Centroid Selection Method based on Radial and Angular Coordinates for K-means Algorithm, p.22-24, International Conference of Computer and Information Technology (ICCIT). 
Halaman ini sengaja dikosongkan 